\section{3'-DEAMINO-3'-MORPHOLINO DERIVATIVES OF DAUNOMYCIN, ADRIAMYCIN AND CARMINOMYCIN}

Sir:

In order to develop anthracyclines useful in cancer treatment, we have been studying the structure-activity relationships of anthracyclines and a variety of analogs including 4'-O-THPadriamycin $^{1)}$ and 4-demethoxy-11-deoxyadriamycin $^{2)}$ have been synthesized.

Herein we describe the synthesis and properties of 3'-deamino-3'-morpholino-daunomycin (1), -adriamycin (2) and -carminomycin (3). Although it was our intention to defer publication up to the complete evaluation of their usefulness, the recent appearance ${ }^{3)}$ of a related study by AcToN et al. prompted disclosure of our results at this time. ACTON et al. applied BoRCH's reductive alkylation to daunomycin and adriamycin, which produced their $\mathrm{C}-13$ hydroxyl derivatives as byproducts as well as the desired $3^{\prime}$-morpholino derivatives, and reported that the $3^{\prime}$-morpholino derivative (1) of daunomycin was active at the 1/40 dose of adriamycin.

The synthesis is based on a new $N$-alkylation method to produce only the desired derivatives 1, 2 and 3 in high yields, using bis(2-iodoethyl)ether and triethylamine in DMF. The reagent, bis(2-iodoethyl)ether was readily obtained in a quantitative yield from commercially available bis(2-chloroethyl)ether and $\mathrm{NaI}^{4)}$. Daunomycin hydrochloride $(20 \mathrm{mg})$ was treated with bis $(2-$ iodoethyl)ether (200 $\mathrm{mg})$ and triethylamine $(0.015 \mathrm{ml})$ in DMF $(1 \mathrm{ml})$ at $20^{\circ} \mathrm{C}$ for 36 hours to give, after extraction (chloroform) and preparative TLC (chloroform - methanol, 9: 1), the corresponding derivative $\mathbf{1}$ in $87 \%$ yield; mp 139 $145^{\circ} \mathrm{C}, \quad[\alpha]_{\mathrm{D}}^{22}+325^{\circ}$ (c 0.1 , acetone), NMR

Fig. 1.

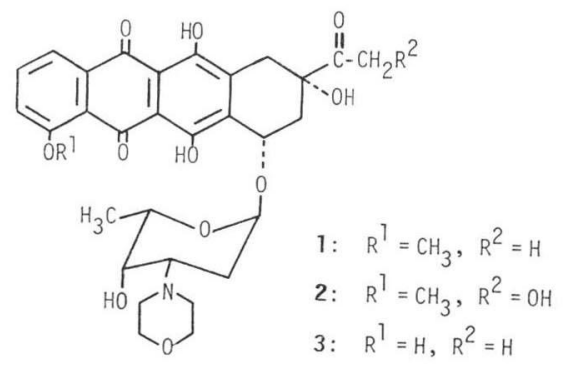

$\left(\mathrm{CDCl}_{3}\right)$ : 1.6 2.7 (m, 9H, H-2', 3', 8 and morpholino $\mathrm{CH}_{2} \times 2$ ), 1.38 (d, 3H, $\mathrm{CH}_{3}-6^{\prime}$ ), 2.40 (s, $\left.3 \mathrm{H}, \mathrm{CH}_{3}-14\right), 3.10$ (AB-q, 2H, $\left.\mathrm{CH}_{2}-10\right), 3.7$ (m, $5 \mathrm{H}, \mathrm{H}-4^{\prime}$ and morpholino $\left.\mathrm{CH}_{2} \times 2\right), 4.07(\mathrm{dq}, 1 \mathrm{H}$, H-5'), Anal found: C 62.01, H 6.12, N 2.10, calcd. for $\mathrm{C}_{31} \mathrm{H}_{35} \mathrm{NO}_{11}$ : C 62.30, H 5.90, N 2.34, FD-MS $597\left(\mathrm{M}^{+}\right)$.

Similarly, $3^{\prime}$-deamino- $3^{\prime}$-morpholino - adriamycin (2) was synthesized from adriamycin in $85 \%$ yield; mp $154 \sim 160^{\circ} \mathrm{C},[\alpha]_{D}^{22}+300^{\circ}$ (c 0.1 , acetone), NMR $\left(\mathrm{CDCl}_{3}\right): 1.6 \sim 2.9$ (m, 9H, $\mathrm{H}-2^{\prime}$, $3^{\prime}, 8$ and morpholino $\left.\mathrm{CH}_{2} \times 2\right), 1.37\left(\mathrm{~d}, 3 \mathrm{H}, \mathrm{CH}_{3}-\right.$ $6^{\prime}$ ), 3.10 (AB-q, $\left.2 \mathrm{H}, \mathrm{CH}_{2}-10\right), 3.7$ (m, 5H, H-4' and morpholino $\left.\mathrm{CH}_{2} \times 2\right), 3.97\left(\mathrm{dq}, 1 \mathrm{H}, \mathrm{H}-5^{\prime}\right)$, Anal. found: C 60.38, H 6.00, N 1.99, calcd. for $\mathrm{C}_{31} \mathrm{H}_{35} \mathrm{NO}_{12}$ : C 60.68, H 5.75, N 2.28, FD-MS $613\left(\mathrm{M}^{+}\right)$. Also, 3'-deamino-3'-morpholinocarminomycin (3) was obtained in $70 \%$ yield; mp $130 \sim 137^{\circ} \mathrm{C},[\alpha]_{\mathrm{D}}^{22}+200^{\circ}$ (c 0.1, acetone), $\mathrm{Rf}$ 0.91 (TLC: chloroform - methanol, 5: 1), NMR: 1.38 (d, $\left.3 \mathrm{H}, \mathrm{CH}_{3}-6^{\prime}\right), 2.40$ (s, $\left.3 \mathrm{H}, \mathrm{CH}_{3}-14\right), 3.12$ (AB-q, 2H, $\mathrm{CH}_{2}-10$ ), Anal. found: C $61.40, \mathrm{H}$ 5.98, N 2.10, calcd. for $\mathrm{C}_{30} \mathrm{H}_{33} \mathrm{NO}_{11}: \mathrm{C} 61.74, \mathrm{H}$ 5.70, N 2.40, FD-MS $583\left(\mathrm{M}^{+}\right)$.

The effect of the derivatives $\mathbf{1}$ and $\mathbf{2}$ on cell proliferation of L1210 leukemia is shown in Table 1 , which indicates the concentrations $(\mu \mathrm{g} / \mathrm{ml})$ required for $50 \%$ growth inhibition on day 2 of the culture. The activity on nucleic acid synthesis is also shown in Table 1 as the $\operatorname{ID}_{50}(\mu \mathrm{g} / \mathrm{ml})$ for $\left[{ }^{14} \mathrm{C}\right]$ thymidine or $\left[{ }^{14} \mathrm{C}\right]$ uridine incorporation into L1210 cells $^{5)}$. Both derivatives 1 and 2 were found to be much more active ( $5 \sim 10$ times) in inhibiting L1210 cell proliferation and RNA synthesis than their parent antibiotics. The antitumor activity of $\mathbf{1}$ and $\mathbf{2}$ against L1210 leukemia was examined. The derivatives were given to $\mathrm{CDF}_{1}$ mice intraperitoneally daily for 10 days starting 24 hours after the inoculation of $10^{5}$ tumor cells. As shown in Table 2, their

Table 1. Inhibitory effects on growth, DNA and RNA synthesis in cultured L1210 cells.

\begin{tabular}{|c|c|c|c|}
\hline & \multicolumn{3}{|c|}{$\mathrm{ID}_{50}(\mu \mathrm{g} / \mathrm{ml})$} \\
\hline & $\begin{array}{l}\text { Growth } \\
\text { (on day 2) }\end{array}$ & DNA & RNA \\
\hline Daunomycin- $\mathrm{HCl}$ & 0.036 & 0.3 & 0.18 \\
\hline Adriamycin- $\mathrm{HCl}$ & 0.03 & 1.65 & 0.68 \\
\hline $\begin{array}{l}\text { 3'-Morpholino- } \\
\text { DM (1) }\end{array}$ & 0.003 & 0.28 & 0.03 \\
\hline $\begin{array}{l}\text { 3'-Morpholino- } \\
\text { ADM (2) }\end{array}$ & 0.006 & 0.2 & 0.05 \\
\hline
\end{tabular}


Table 2. Antitumor activities (T/C \% of the survival period) on L1210.

\begin{tabular}{|c|c|c|c|c|c|c|c|c|c|c|c|c|}
\hline & \multicolumn{12}{|c|}{ Dose $(\mu \mathrm{g} / \mathrm{kg} / \mathrm{day})$} \\
\hline & 1250 & 625 & 312 & 200 & 156 & 100 & 78 & 50 & 25 & 12.5 & 6.25 & 3.12 \\
\hline Daunomycin- $\mathrm{HCl}$ & 235 & 157 & 145 & & 102 & & 102 & & & & & \\
\hline Adriamycin- $\mathrm{HCl}$ & 229 & 235 & 157 & & 120 & & 108 & & & & & \\
\hline 3'-Morpholino-DM (1) & & & & Toxic & & $205^{*}$ & & 120 & 114 & 120 & 96 & \\
\hline 3'-Morpholino-ADM (2) & & & & & & & & Toxic & $90^{*}$ & 151 & 108 & 108 \\
\hline
\end{tabular}

Table 3. Rf values on TLC with chloroformmethanol $(5: 1)$.

\begin{tabular}{c|c}
\hline & Rf values \\
\hline Daunomycin & 0.07 \\
Adriamycin & 0.02 \\
Aclacinomycin & 0.88 \\
$\mathbf{1}$ & 0.89 \\
$\mathbf{2}$ & 0.78 \\
$\mathbf{3}$ & 0.91 \\
\hline
\end{tabular}

effective dose ranges were very narrow, namely, the optimal dose of the daunomycin derivative 1 was only about $100 \mu \mathrm{g} / \mathrm{kg}$, and that of the adriamycin derivative 2 was $12.5 \mu \mathrm{g} / \mathrm{kg}$, indicating that these derivatives were very potent but have a strong toxicity. Derivatives $\mathbf{1}$ and $\mathbf{2}$ were also found to cause death by oral administration, when examined in $\mathrm{CDF}_{1}$ mice: $\mathrm{LD}_{50} 1,000 \mu \mathrm{g} / \mathrm{kg}$ and $500 \mu \mathrm{g} / \mathrm{kg}$, respectively. The acute toxicity by intraperitoneal injection was as follows: $\mathrm{LD}_{50} 500 \mu \mathrm{g} / \mathrm{kg}$ and $250 \mu \mathrm{g} / \mathrm{kg}$ for 1 and 2 . It indicates the possible absorption by oral administration.

Comparison of $\mathrm{Rf}$ values of these derivatives with that of orally active aclacinomycin ${ }^{()}$, as shown in Table 3, suggests that $\mathrm{Rf}$ value more than approximately 0.7 may be a factor for the oral absorption of anthracyclines.

\section{Acknowledgements}

This work was supported by a grant-in-aid for cancer research from the Ministry of Education, Science and Culture, Japan.

\author{
YOSHIKAZU TAKAHASHI \\ Mitsuhiro KinOSHITA* \\ TORU MASUdA \\ KUniaki TATSUTA* \\ TOMIO TAKEUCHI \\ Hamao Umezawa
}

\begin{abstract}
Institute of Microbial Chemistry 14-23 Kamiosaki, 3-chome Shinagawa-ku, Tokyo 141, Japan *Department of Applied Chemistry Keio University, Hiyoshi, Yokohama, Kanagawa, Japan
\end{abstract}

(Received October 8, 1981)

\section{References}

1) Umezawa, H.; Y. Takahashi, M. Kinoshita, H. Naganawa, T. Masuda, M. Ishizuka, K. TATSUTA \& T. TAKeUChI: Tetrahydropyranyl derivatives of daunomycin and adriamycin. $\mathrm{J}$. Antibiotics 32: 1082 1084, 1979

2) Umezawa, H.; Y. Takahashi, M. Kinoshita, H. Naganawa, K. Tatsuta \& T. Takeuchi: Synthesis of 4-demethoxy-11-deoxy-analogs of daunomycin and adriamycin. J. Antibiotics 33: $1581 \sim 1585,1980$

3) Acton, E. M.; C. W. Mosher \& J. M. Gruber: Approaches to more effective anthracyclines by analog synthesis and evaluation. Abstracts of 182nd National Meeting of the American Chemical Society, Carb. 10, New York, Aug. 23 28, 1981

4) Gibson, S. G. \& J. D. A. Johnson: CCCXXXIII. Syntheses with $\beta \beta^{\prime}$-dichlorodiethyl ether. I. Derivatives of tetrahydropyran. J. Chem. Soc. 1930: $2525 \sim 2530,1930$

5) OKI, T.; T. Takeuchi, S. OKa \& H. Umezawa: New anthracycline antibiotic aclacinomycin $A$ : Experimental studies and correlations with clinical trials. In "Recent Results in Cancer Research, Vol. 76”, pp. 21 40, Ed. S. K. Carter, Y. Sakurai \& H. Umezawa, SpringerVerlag, Berlin-Heidelberg, 1981

6) Oki, T.; Y. Matsuzawa, A. Yoshimoto, K. Numata, I. Kitamura, S. Hori, A. Takamatsu, H. Umezawa, M. Ishizuka, H. Naganawa, H. Suda, M. Hamada \& T. Takeuchi: New antitumor antibiotics, aclacinomycins $\mathrm{A}$ and $\mathrm{B}$. J. Antibiotics 28: 830 834, 1975 